\title{
Modelling the effect of different agricultural practices on stream nitrogen load in central Germany
}

\author{
Seifeddine Jomaa ${ }^{1,2^{*}}$, Sanyuan Jiang ${ }^{3}$, Daniela Thraen ${ }^{2,4}$ and Michael Rode ${ }^{1}$
}

\begin{abstract}
Background: Understanding the response of nitrogen fluxes to changes in land use and agricultural practices is crucial for improving the instream water quality prediction. In central Germany, the expansion of bioenergy crops during the last decade led to an increase in fertiliser application rates. The purpose of this study is to investigate the effect of agricultural management changes on the stream nitrogen load of a drinking water reservoir catchment (Weida, $99.5 \mathrm{~km}^{2}$ ) using a hydrological water quality model.
\end{abstract}

Methods: The semi-distributed hydrological water quality model—-the HYdrological Predictions for the Environment (HYPE) — was calibrated and validated successfully for discharge and nitrate-N concentrations during the period 1997-2003 (the lowest discharge Nash-Sutcliffe efficiency (NSE) was 0.78). Subsequently, stream nitrogen load of six different land use scenarios and their associated agricultural practice changes were compared to the baseline simulations of the period 2006-2009. Some of these scenarios were designed considering the increased cultivation of bioenergy crops.

Results: Results revealed that an increase in mineral fertiliser by $20 \%$ for all crops augmented an increase of monthly stream nitrogen loads in the range of 2-6\% compared to the baseline simulations. Also, it was found that stream nitrogen load increased in scenarios where all or some crop areas were converted to maize and rape, which are the established bioenergy crops in Germany. The increase of nitrogen load resulting from these scenarios differed in terms of magnitude and their temporal patterns, reflecting the importance of timing, the amount of fertiliser applications, and harvesting periods. However, results showed that nitrogen load was reduced in situations when only organic farming or summer barley was used and when rape and maize cropping areas were converted to winter wheat.

Conclusions: In this intensively used agricultural catchment, the simulated stream nitrate-N loads quickly responded to fertiliser application changes (increase/decrease). This rapid response could be explained by short residence time of the interflow and baseflow runoff components because of the hardrock geological properties of the catchment.

Keywords: HYPE model, Stream nitrogen load, Nitrate-N $\left(\mathrm{NO}_{3}-\mathrm{N}\right)$, Bioenergy, Land use change, Agricultural practices

\section{Background}

Bioenergy plants can play an important role in fulfilling the world's increasing energy demand, by mitigating climate change-mainly through the reduction of greenhouse gas (GHG) emissions-improving socio-economic

\footnotetext{
* Correspondence: seifeddine.jomaa@ufz.de

${ }^{1}$ Department of Aquatic Ecosystem Analysis and Management, Helmholtz Centre for Environmental Research_UFZ, Brueckstrasse 3a, 39114 Magdeburg, Germany

${ }^{2}$ Department of Bioenergy, Helmholtz Centre for Environmental Research-UFZ, Permoserstrasse 15, 04318 Leipzig, Germany Full list of author information is available at the end of the article
}

equity and preserving the biodiversity [1-3]. During the last decades, Germany has set the goal of adopting a modern, environment-friendly and sustainable supply of energy by expanding renewable energy [4]. This initiative is integrated with that of the European Union (EU), which, by 2020, aims to lower the GHG emissions and energy consumption by $20 \%$ and also aims to cover $20 \%$ of energy needs by using renewable energy $[4,5]$. Within this framework, the member states of the EU have defined their own national targets and strategies. Among these, Germany is determined to increase the 
share of its energy from renewable resources to achieve $18 \%$ [6] and consequently reduce the GHG emissions by at least $40 \%$, by 2020, as compared to its use in 1990 [4]. In Germany, bioenergy represents the greatest contribution to all regenerative energy sources (about $66 \%$ in 2012, where energy crops supply only a minor share of it) and will continue playing an essential role in future energy supply as well. However, to fulfil the increasing energy demands, sustainability is a key factor in developing an appropriate national bioenergy industry, especially concerning the ability to produce enough biomass without environmental decline [7, 8].

The impact of bioenergy practices on water resources currently involves the conversion of agricultural land, originally used for food production, to grow bioenergy crops. In Germany, arable land that has been converted to grow bioenergy crops is about $21 \%$ in 2012, and this share has been projected to achieve ranges of 24-29\% and $27-34 \%$ by 2020 and 2030, respectively [9]. For instance, the area of land cultivated with maize (Zea mays) - which is well known as the best actual biogas feedstock-has increased considerably over the recent years in Germany [10], and it ranks as the third important crop [11]. Agriculture is responsible for the largest contribution of non-point nitrogen source pollution in Germany $[12,13]$. For the continued cultivation of bioenergy crops, feedstock production will require increased fertiliser input, which may have environmental implications $[14,15]$. For example, maize requires more fertilisers than other crops [16], even though it can use the mineral and organic fertiliser effectively [17]. The effects of bioenergy crops on water quality are either positive or negative, and their magnitude depends on the local and regional factors, such as types of land use, topography, soils, climatic conditions, irrigation and agricultural management [18-20]. For instance, a study of the impact of switching a million hectares of pastures and hay lands to energy crops (mainly switchgrass and corn stover) on the water quality in the Upper Mississippi River showed an ambivalent effect [19]. The energy crops significantly increased the suspended sediment and its associated instream total phosphorus, while it decreased the nitrate loads. This was attributed in part to the nitrogen uptake from the soil by the improved energy crops. Also, this was explained by the decreased nitrogen transport and reduction of denitrification losses because of the reduced flow and soil moisture, respectively [19]. However, the conversation of pastures to row crops (i.e. maize) increased the eroded suspended sediment, especially after crop harvest, which in turn resulted in high instream phosphorus loading. Therefore, it was imperative to evaluate the agriculture land use changes resulting from these bioenergy strategies and its effect on the regional water quality, especially in a region like central
Germany, an area where the land use was agriculturedominant and had experienced increased biofuel production during the previous years.

Numerous studies have shown that changes in land cover/use significantly affect the hydrological regime, which in turn influences the surface and groundwater quality. It is known that at the catchment scale, hydrological modelling is a favourable tool for discharge and nutrient transport (such as nitrogen and phosphorus) predictions. Simulation models such as the Soil and Water Assessment Tool (SWAT) model (e.g. [21, 22]) and other models such as the Jena Adaptive Modelling System (JAMS) [23] have been increasingly applied to study the impact of agricultural management practices on soil, groundwater and instream water quality through scenario analysis. For instance, the impact of conservation tillage and intercropping buffer strips was quantified in two watersheds in central Iowa in the USA [24]. In addition, the SWAT model was used to predict the possible long-term effects of large scale bioenergy cropping system expansion on soil and water quality using different land use and crop rotation scenarios [14, 15, 25-27]. Among these models, the HYdrological Predictions for the Environment (HYPE) model is a spatially semi-distributed and process-based hydrological water quality model [28]. The HYPE model simulates discharge and nutrient concentrations based on commonly available and easily measurable agriculture practices and climate data (precipitation and air temperature). The HYPE model maintains a good balance between model complexity and representation of internal hydrological water quality routines, such as nutrient transport and transformation processes [29]. It has been shown that the HYPE model can represent the measured hydrological response and its associated geochemical components in a consistent manner in catchment areas with different physiographic characteristics [28-31]. It has also been shown that for model parameter identification, the multi-objective calibration approach is more efficient compared to the stepwise calibration technique, which is traditionally used for hydrological water quality modelling (e.g. $[32,33])$. Thus, including the water quality observations into the hydrological parameter identification helps to better identify the flow partitioning into surface flow, interflow and groundwater components, which are essential for acquiring accurate water quality parameters [34]. As mentioned earlier, it is important to understand the hydrological water quality response to land use changes when taking the bioenergy policies into account, in central Germany. Therefore, the objective of this study is twofold: (i) to evaluate the agricultural land changes that have occurred at the Weida catchment area after the adoption of the bioenergy strategies and (ii) to assess the implications of the bioenergy-related aspects on the instream nitrogen loads. 


\section{Methods}

\section{Study areas}

The selected catchment area for this study is Weida $\left(99.5 \mathrm{~km}^{2}\right)$, which is one small tributary of the Elbe river basin and is located in Thuringian state, in Germany (Fig. 1). The dominating land use classes of the Weida catchment area are arable land (40\%), forest (29\%) and pastures $(26 \%)$, which are all located in a low-mountain range (elevation between 357 and $552 \mathrm{~m}$ ). Considering the whole catchment area, no clear spatial pattern of dominant land use can be observed; rather, the whole river basin is characterised by a mixture of the three most dominant land use classes (Fig. 1). The Weida river basin has one gauging station at the catchment outlet (Laewitz, Fig. 1), where discharge and nitrate-N concentrations are measured. The Weida catchment feeds into the Zeulenroda and Weida drinking water reservoirs $[35,36]$. These reservoirs are part of the Thuringia remote water supply system, which have also received variable flow from the Loessau reservoir during the period 19942004. It is located outside of the Weida catchment area (Fig. 1). The geology of Weida is dominated by clay, schists and eruptive rocks, where most of these rocks have low permeability [36]. This geological feature induces the quick flow to be the dominant runoff component in the Weida catchment. It has been reported that the bedrock range has developed from shallow rankers to welldeveloped cambisols and fluvisols in the stream valleys [35]. In this catchment area, sandy loam and silty loam are the most dominant soil classes (Table 1). In this study, five precipitation stations have been considered, where the mean annual precipitation rate is about $640 \mathrm{~mm}$ based on the measurement during the period 1988-2004. The mean annual temperature is about $7{ }^{\circ} \mathrm{C}$ in the Weida catchment. The long-term mean discharge at the outlet Laewitz gauging station is about $0.72 \mathrm{~m}^{3} \mathrm{~s}^{-1}$. In this catchment, nutrient inputs from agricultural land represent the main instream eutrophication sources. The dominant crops are

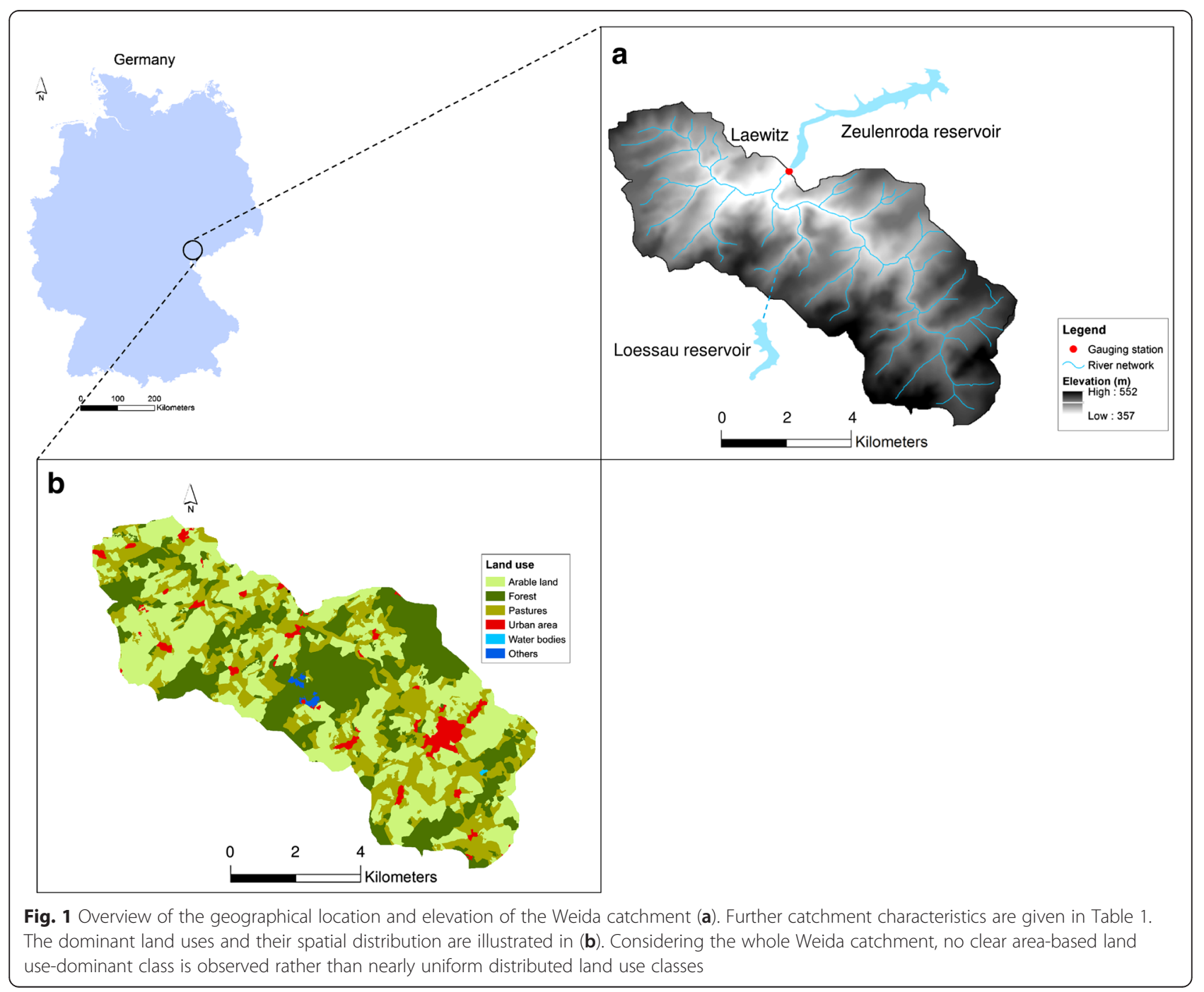


Table 1 Characteristics of the Weida catchment

\begin{tabular}{ll}
\hline & Weida \\
\hline Area $\left(\mathrm{km}^{2}\right)$ & 99.5 \\
Elevation (m a.s.l) & $357-552$ \\
Land use & \\
$\quad$ Arable land (\%) & 40.0 \\
Forest (\%) & 29.0 \\
Pastures (\%) & 26.0 \\
$\quad$ Urban (\%) & 5.0 \\
Population density & 80 \\
Geology (-) & $\mathrm{Clay} \mathrm{schist} \mathrm{and} \mathrm{eruptive} \mathrm{rocks}$ \\
Soil (-) & Sandy loam and silt loam \\
Main temperature $\left({ }^{\circ} \mathrm{C}\right)$ & 7 \\
Mean annual precipitation $\left(\mathrm{mm} \mathrm{year}^{-1}\right)$ & 640 \\
Mean discharge $\left(\mathrm{m}^{3} \mathrm{~s}^{-1}\right)$ & $0.72^{\mathrm{a}}$ \\
Mean specific discharge $\left(\mathrm{I} \mathrm{s}^{-1} \mathrm{~km}^{2}\right)$ & 7.24 \\
Mean $\mathrm{NO}_{3}{ }^{-\mathrm{N}}$ concentration $\left(\mathrm{mg} \mathrm{I}^{-1}\right)$ & $8.81^{\mathrm{b}}$
\end{tabular}

aperiod considered is $1975-2004$

beriod considered is 1997-2003

winter wheat, winter and summer barley, rape, maize and grassland. The average fertiliser application rates (organic and mineral) are listed in Table 2 [35]. In the Weida catchment, both discharge and nitrate-N concentration data are characterised by high seasonal variability, where higher values occur during the wet period (October-April) and lower values are observed during the dry period (May-September). The mean instream nitrate- $\mathrm{N}$ concentrations are 8.80, 9.93 and $8.76 \mathrm{mg} \mathrm{l}^{-1}$ for the periods 1983-1987, 1989-1996 and 1997-2003, respectively.

For model application in the Weida catchment, the periods 1997-2003 and 2006-2009 were considered for model calibration and validation of discharge and nitrate- $\mathrm{N}$ concentrations. Measured daily discharge and daily (1996-2003) and weekly to bi-weekly (2006-2009) nitrate- $\mathrm{N}$ concentrations at the Laewitz gauging station were used for modelling purposes.

As mentioned above, the agriculture land represents about $66 \%$ of the Weida catchment affecting the

Table 2 The crop share of agricultural land area (\%) and their annual nitrogen-fertiliser amount $\left(\mathrm{kg} \mathrm{N} \mathrm{ha}^{-1}\right.$ year $\left.^{-1}\right)$ used during the baseline simulation

\begin{tabular}{llccc}
\hline Crops & Share (\%) & Organic N & Mineral N & Total N \\
\hline Grassland & 21 & 69.2 & 36.0 & 105.2 \\
Winter wheat & 25 & 46.3 & 130.5 & 176.8 \\
Rape & 19 & 58.4 & 145.8 & 204.2 \\
Winter barley & 13 & 48.6 & 125.0 & 173.6 \\
Summer barley & 12 & 35.4 & 62.1 & 97.5 \\
Maize & 10 & 78.2 & 112.6 & 190.8 \\
\hline
\end{tabular}

instream water quality and in consequence the water quality of the Weida-Zeulenroda-Loessau reservoir (Fig. 1). The historical discharge and nitrate- $\mathrm{N}$ concentration measurements during the period 1983-2003, at the Laewitz gauging station, show that the instream nitrogen concentrations have increased after the reunification of Germany in 1990 compared to the previous periods (Fig. 2). However, no clear trend has been observed for discharge during the entire period of 1983-2003 (black dashed line, Fig. 2). Nevertheless, at least three different stages can be easily distinguished for the instream nitrate- $\mathrm{N}$ concentrations. Constant to slightly reduced nitrate-N concentrations have been observed during the interval 1983-1987, with an average concentration of $8.80 \mathrm{mg} \mathrm{l}^{-1}$ (blue dashed line, Fig. 2). An increase in concentration, however, has been measured for the period 1989-1996, with an average concentration of $9.93 \mathrm{mg} \mathrm{l}^{-1}$ (red dashed line, Fig. 2). This was mainly explained by the rapid increase of fertiliser application to improve the crop yield. Subsequently, a constant phase appears again with an average concentration of about $8.91 \mathrm{mg} \mathrm{l}^{-1}$ during the period 1997-2003 (green dashed line, Fig. 2). This can be explained by the adopted catchment management strategy during this period as detailed in Fig. 2. There are no accurate measurements in terms of fertiliser rates during the period 1990-1997, but it has been reported that fertiliser application had been increased, at least by $20 \%$, compared to the period 1983-1989.

In order to reduce the impact of diffuse nutrient leaching from the farmland in the reservoir, in 1997, the Thuringian Reservoir Administration (TTV) developed a catchment management strategy with the farmers. This consisted of encouraging the farmers to limit fertiliser application in their individual fields, which in turn would reduce instream nitrogen concentration. This procedure comprised of land use restrictions between the farmers and the TTV, which was based on legal rules and individual agreements. On the other hand, these land use restrictions were compensated financially by using field-specific measures [37]. Only a limited budget was available for compensation payments, and the TTV was therefore interested in optimising this agricultural management strategy. Thus, the water authority (TTV) intended to impose restrictions only where it was necessary and oversee whether the farmers were really keeping in line with their individual contracts. Therefore, the TTV supervised land use restrictions in the Weida catchment during the period 1997-2009 using the following actions:

- Recording the land use management of the individual fields

- Inspecting the nitrogen application (amount and timing) of each individual field 


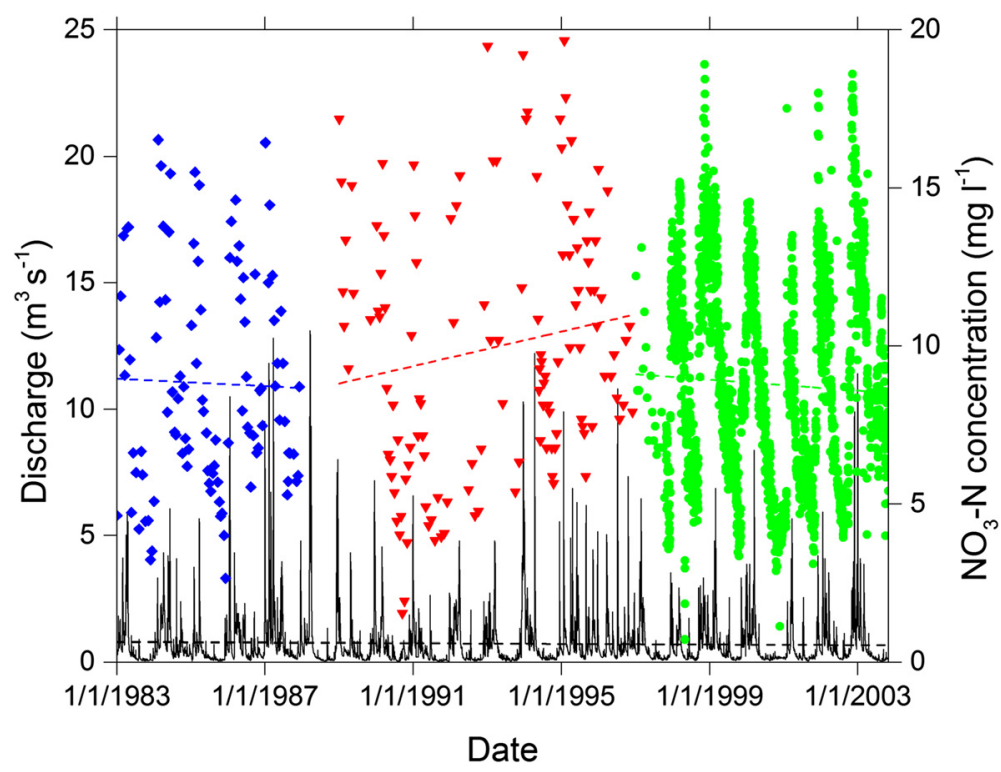

Fig. 2 The measured discharge and nitrate-N concentrations for the period 1983-2003. The discharge was measured at a daily time interval. The $\mathrm{NO}_{3}-\mathrm{N}$ concentrations were only measured at daily time steps during the period 1997-2003 (green circle points), while for the earlier periods 19831987 and 1989-1996, they were measured at weekly and bi-weekly time steps, presented here with blue diamond and red triangle markers, respectively

- High-resolution measurement of the nitrate- $\mathrm{N}$ concentrations and flow rate at the main inflow of the Zeulenroda reservoir (Laewitz gauging station)

\section{Modelling approach}

The continuous, semi-distributed and process-based hydrological water quality HYPE model has been used for this study. The HYPE model has been presented in details elsewhere (e.g. [28, 30]), so here, only a summary is given. The HYPE model has been developed based on the previous HBV-NP model [38, 39]. First, the model delineates the whole catchment into sub-basin systems based on the digital elevation model and stream network. Second, each sub-basin is divided into different soil-land use combinations (SLCs) by the overlapping soil and land use maps. Each SLC corresponds to a unique hydrological response unit (HRU). Each SLC is defined as a percentage of the sub-basin area and is not coupled with the geographical location. Different vegetation types, such as forest and crop area, are simulated as separate land uses. In the HYPE model, the soil can be divided into a maximum of three layers, which can be specified with different thicknesses (Fig. 3). The model parameters are soil or land use-dependent, even as some model parameters are assumed to be general parameters for the whole catchment. Simulations start from a standard initial state and a warming up period of typically 1 year, which is excluded from the model evaluation. The HYPE model simulates streamflow and nutrient concentrations in the water, such as inorganic and organic nitrogen (IN and $\mathrm{ON}$, respectively) and dissolved and particulate phosphorus (SP and PP, respectively). In addition, it can compute the total nitrogen (TN) and total phosphorus (TP) as the sum of the relevant fractions. The dissolved organic carbon (DOC) and other nitrogen and phosphorus factions (e.g. humusN and humusP) can be also simulated within the soil, but the runoff leaving the soil contains only the nutrient fractions mentioned above. Conservative tracers can also be modelled. A more detailed description of the hydrologic and nitrogen processes of the HYPE can be found elsewhere [28, 30].

\section{Model setup in the Weida catchment}

The HYPE model (version 3.5.3) was set up for discharge and nitrate- $\mathrm{N}$ simulations at the Weida gauging station, at Laewitz, for the periods 1997-2003 and 2006-2009. The Weida catchment was divided into 37 sub-basins, and 16 SLCs were defined according to the model setup. Within each sub-basin, the areas with similar land use and soil type were grouped together into a single SLC and the different SLCs within a sub-basin were not spatially distributed.

First, the HYPE model was calibrated for the period 1997-1999, and subsequently, it was validated for the periods 2000-2003 and 2006-2009. One year (1996) of warming up of the model was utilised, which was excluded from the model evaluation. After validation of the model, the effects of different land use changes and agricultural management practices on the instream water quality were tested, using the appropriate scenarios. 


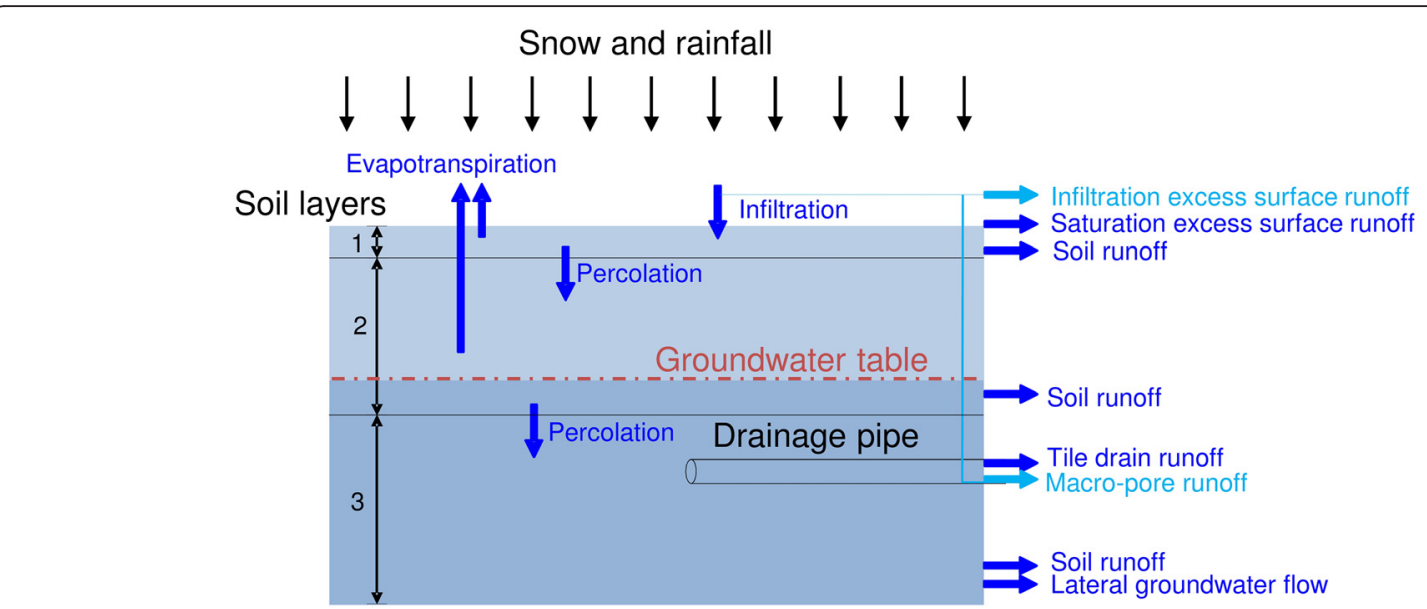

Fig. 3 An overview about the different runoff calculations of the HYPE model

The HYPE model parameters are general or coupled with soil type or land use. In addition, the model parameters are connected to the physiographical characteristics of the catchment area and are not dependent on the division into sub-basins [28]. This feature was considered in the development of the HYPE model to improve its transferability and increase its applicability in ungauged basins.

In order to minimise the equifinality problem during the calibration phase, only the most sensitive model parameters have been optimised. The parameter identification procedure follows three steps. First, a manual sensitivity analysis is utilised for the identification of model parameters using a one-factor-at-a-time approach (OFAT) [31]. At this stage, the initial parameter values are estimated based on their physical meanings, the literature review of former model applications and the gained knowledge from the Weida catchment. Finally, the sensitive parameters obtained during the previous stage are optimised using the Parameter ESTimation (PEST) tool. In this step, reasonable initial guesses and ranges are defined by referring to the parameter settings in the applications of early versions of the HYPE model applications [28-31] and results from iterative manual calibrations. Detailed descriptions of parameter sensitivity analyses and their uncertainty have been described elsewhere (e.g. [29, 31]).

\section{Model evaluation}

To evaluate the model performance, both statistical and graphical techniques were used as recommended in the literature (e.g. [40]). One of the quantitative statistical parameters chosen for evaluation of the model was the Nash-Sutcliffe [41] efficiency (NSE). The NSE reflected the capability of the model to represent the dynamic behaviour of the measured parameter and quantified the relative magnitude of the residual variance compared to the measured data variance. For testing the reasonability representation of the water and matter flux (loads) balance by the HYPE model, another statistical parameter was used, which was the percentage bias (PBIAS). The NSE and PBIAS were determined using the following equations:

$$
\begin{gathered}
\mathrm{NSE}=1-\frac{\sum_{i=1}^{n}\left(Y_{i}^{\mathrm{obs}}-Y_{i}^{\mathrm{sim}}\right)^{2}}{\sum_{i=1}^{n}\left(Y_{i}^{\mathrm{obs}}-\overline{Y^{\mathrm{obs}}}\right)^{2}}, \\
\mathrm{PBIAS}=\frac{\sum_{i=1}^{n}\left(Y_{i}^{\mathrm{sim}}-Y_{i}^{\mathrm{obs}}\right) \times 100}{\sum_{i=1}^{n} Y_{i}^{\mathrm{obs}}},
\end{gathered}
$$

where $Y_{i}^{\text {sim }}$ and $Y_{i}^{\text {obs }}$ are the $i$ th simulated and observed discharge, respectively; $\overline{Y^{\text {sim }}}$ and $\overline{Y^{\text {obs }}}$ are the mean values of the simulated and observed discharges, respectively; and $n$ is the total number of observations.

The NSE varies between infinity and 1 , with NSE $=1$ being the optimal value. The optimal value of PBIAS is 0 (e.g. the water balance is $100 \%$ captured). Low PBIAS in absolute values indicate accurate model simulation. Positive values indicate model overestimation bias, and negative values indicate model underestimation bias.

\section{Baseline and scenario development}

The baseline simulation has been conducted using the collected data resulting from the agreement between the TTV and farmers, as described in the "Discharge simulations" section. Accordingly, the share of different crops to agricultural area and their corresponding fertiliser application amounts, which are given in Table 2, have been considered in the model baseline setup. 
To investigate the effect of land use and crop changes on nitrogen instream load in the period 2006-2009, different agricultural practice scenarios were designed. Some of these scenarios were developed considering the increase in bioenergy crops in the region, based on suitability and practicality. The definition of these scenarios was carried out in close collaboration with stakeholders and agricultural agencies to ensure a high degree of acceptance by the farmers. The projected scenarios also covered a wide range of realistic and site-specific agricultural management practices that could increase or reduce the nitrogen loads, as detailed a little further in the text. For consistent comparison between the different scenarios, each scenario was compared to the baseline simulations, which were the model predictions of the real situation during the considered period.

For the baseline simulation, the agricultural management practices that occurred in the period 2006-2009 were simulated by the HYPE model, using the administrative information derived from a survey conducted by the drinking water reservoir authority. For instance, the mineral and organic fertiliser amounts and their corresponding application timings were adjusted as inputs in the model based on the measured values obtained from the farmers as per the agreement with the TTV authority, as explained above. The predicted nitrate- $\mathrm{N}$ loads obtained from the baseline simulations were compared to six scenarios. In the first scenario (denoted as S1), the fertiliser application for all crops was increased by $20 \%$. This scenario was designed to evaluate the nitrogen loads without the agricultural catchment management strategy, which was developed in 1997 by the TTV to reduce the instream nitrogen concentration that was observed during 19891996, after the reunification of Germany. In other words, the $\mathrm{S} 1$ scenario was suggested to observe as to what extent the fertiliser restriction initiative could affect the nitrogen loads. Another scenario was developed based on the assumption that only organic farming is applied (no mineral fertiliser). This scenario, denoted as S2, was developed to answer the question - to what extent could the Zeulenroda drinking water reservoir be protected when only organic farming was applied to the entire agricultural lands? The third scenario (S3) was developed based on the assumption that all agricultural areas were converted to maize, which was well known as one of the biogas feedstock for bioenergy production. Also, the conversion of all crops to summer barley was considered as scenario 4 (S4). In scenario 5 (S5), the crop areas that were originally occupied by rape and maize were converted to winter wheat. Here, it is worth mentioning that barley and winter wheat were known as two crops for bioethanol production. In the last scenario, the winter wheat and maize crop areas were converted to rape (S6), which was known as a biodiesel crop.
The comparison between each scenario and baseline predictions was conducted in terms of nitrate- $\mathrm{N}$ loads in monthly time steps. First, the daily nitrate-N load was calculated by multiplying the measured/simulated $\mathrm{NO}_{3}-\mathrm{N}$ concentration with its corresponding accumulated daily discharge. Next, the measured monthly load $(L)$ was estimated using the following interpolation method (equation 3), with continuous discharge measurements and regular sampling of nitrate- $\mathrm{N}$ concentrations [42]:

$$
L=\frac{K \sum_{i=1}^{n}\left(C_{i} Q_{i}\right)}{\sum_{i=1}^{n} Q_{i}} \times \bar{Q}_{r}
$$

where $K$ is a conversion factor accounting for the period of load estimation and measurement units, $C_{i}$ is sample concentration, $Q_{i}$ is the flow at sample time and $\bar{Q}_{r}$ is the mean flow for the period of interest (derived from a continuous flow record).

\section{Results and discussion}

\section{Discharge simulations}

A multi-objective calibration approach was utilised to setup the HYPE model at the Weida catchment. The model was calibrated for the period January 11, 1997October 31, 2000, and was then validated for the period January 11, 2000-October 31, 2003, at the Laewitz basin gauging station. The HYPE model could reproduce the measured daily discharge reasonably well (NSE were about 0.78 and 0.82 for the calibration and validation periods, respectively) (Fig. 4). The dynamic behaviour of the measured discharge was captured well by the model. Some extreme rainfall events, however, were slightly under- or overestimated, affecting the model performance. The HYPE model predicted the streamflow at daily intervals using the daily precipitation, limiting an accurate prediction of extreme events, which were usually generated by high rainfall intensity at shorter time intervals (hourly) [31]. The water balance was also reproduced well during the calibration and validation periods (PBIAS $<10 \%$ ). Overall, the model slightly over-predicted the water balance during the calibration (PBIAS $=3.74 \%$ ) and validation periods (PBIAS $=7.28 \%$ ). This overestimation could lead to unbalanced nitrate- $\mathrm{N}$ calculations. The most sensitive discharge-related parameters, their physical meanings and optimised values are listed in Table 3. The highest controlling parameter for discharge simulations was the potential evapotranspiration rate of the arable land (cevp), which was the dominant land use share (40\%) in the whole catchment area (Table 1). The additional sensitive discharge-related parameters contained the uppermost soil layer runoff coefficient of the 


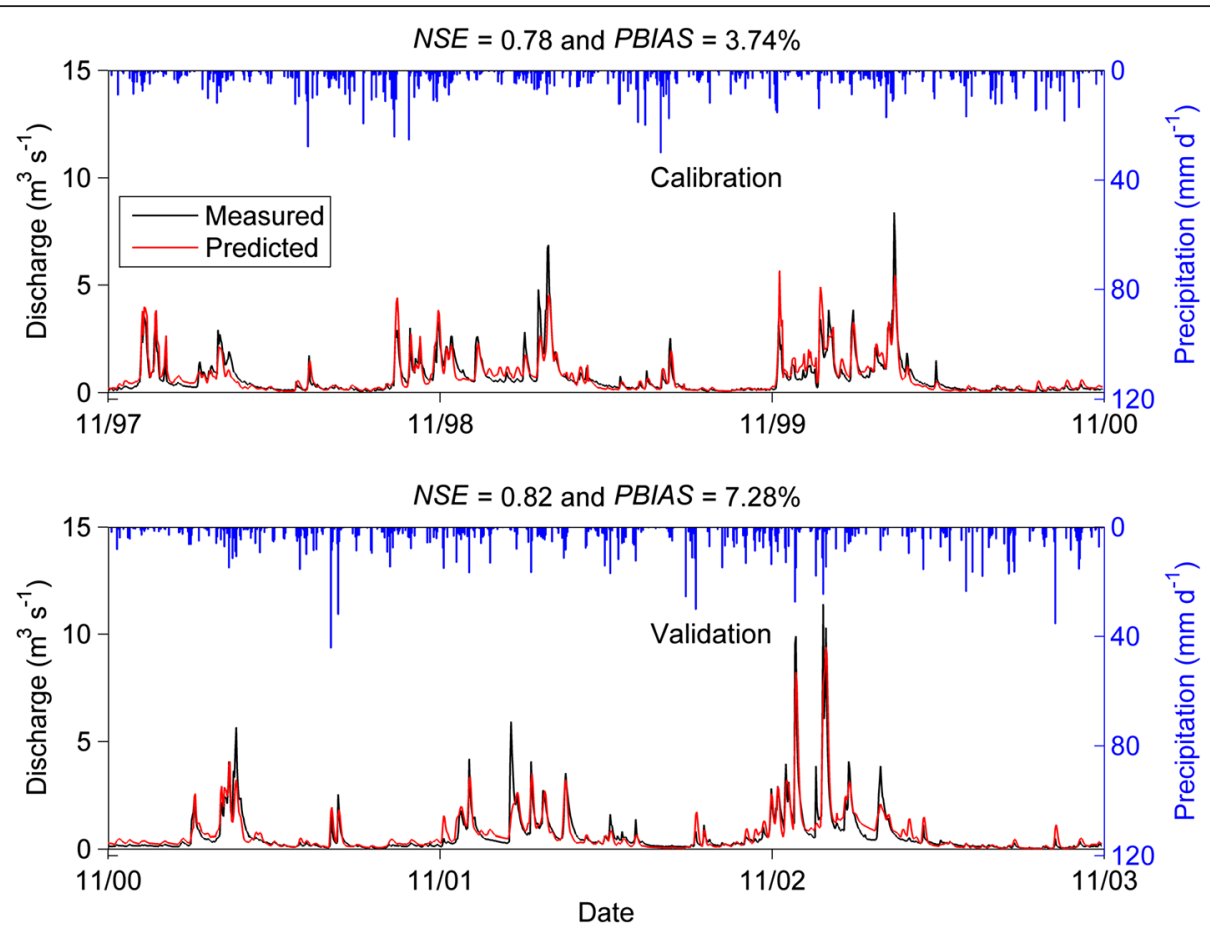

Fig. 4 Measured and predicted discharge at the Laewitz gauging station for the calibration (1997-2000) and validation (2000-2003) periods. The HYPE model could reproduce significantly well the dynamical behaviour of the measured discharge (lowest NSE $=0.78$ ). Also, the water balance was well captured by the model during the whole simulation periods (with highest PBIAS of about $7.28 \%$ )

dominant sandy loam soil (rrcs1), the maximum velocity in the stream channel (rivvel), the runoff coefficient for regional groundwater flow (rcgrw) and the decrease of evapotranspiration with the soil depth (epotdist). Similar controlling discharge simulation parameters were found in a previous study conducted in the meso-scale Selke catchment $\left(463 \mathrm{~km}^{2}\right)$, located in Sachsen-Anhalt state
(Germany), using the same HYPE model [31]. However, the best optimised values differed between both catchments. This discrepancy in terms of best optimised parameters could be explained by the difference in the climate forcing data, topographical and physiographical characteristics between the two catchment areas.

Table 3 The most sensitive hydrological parameters, their physical meanings and their optimised values of the HYPE model for discharge and nitrate-N simulations

\begin{tabular}{|c|c|c|c|c|}
\hline Parameter & Physical meaning & $\begin{array}{l}\text { Sensitivity } \\
\text { rank }\end{array}$ & Initial range & $\begin{array}{l}\text { Optimized } \\
\text { value }\end{array}$ \\
\hline $\begin{array}{l}\text { cevp } \\
\text { Arable land }\end{array}$ & Potential evapotranspiration rate $\left(\mathrm{mmd}^{-1}{ }^{\circ} \mathrm{C}^{-1}\right)$ & 1 & $0.01-1.50$ & 0.1038 \\
\hline $\begin{array}{l}\operatorname{rrcsl} \\
\text { Sand loamy }\end{array}$ & Soil runoff coefficient for the uppermost soil layer $\left(\mathrm{d}^{-1}\right)$ & 2 & $0.001-1$ & 0.0400 \\
\hline rivvel & Maximum velocity in the stream channel $\left(\mathrm{ms}^{-1}\right)$ & 3 & $0.001-1$ & 0.0560 \\
\hline rcgrw & Runoff coefficient for regional groundwater flow $\left(\mathrm{d}^{-1}\right)$ & 4 & $0.0001-0.1$ & 0.0400 \\
\hline epotdist & Decrease of evapotranspiration with soil depth $\left(\mathrm{m}^{-1}\right)$ & 5 & $1-10$ & 5.4169 \\
\hline denitr & Denitrification rate in soil $\left(\mathrm{d}^{-1}\right)$ & 1 & $0.001-0.1$ & 0.0727 \\
\hline $\begin{array}{l}\text { uptsoill } \\
\text { Arable land } \\
\text { Forest } \\
\text { Grassland }\end{array}$ & Fraction of nutrient uptake in the uppermost soil layer $(-)$ & 2 & $\begin{array}{l}0.001-1.0 \\
0.001-1.0 \\
0.001-1.0\end{array}$ & $\begin{array}{l}0.8000 \\
0.8000 \\
0.5000 \\
\end{array}$ \\
\hline fertdays & $\begin{array}{l}\text { Number of days that fertiliser applications occur counting from the first } \\
\text { application and forward using the same amount every day }(-)\end{array}$ & 3 & $10-150$ & 60 \\
\hline denitw & Parameter for the denitrification in water $\left(\mathrm{kgm}^{2} \mathrm{~d}^{-1}\right)$ & 4 & $1 \times 10^{-6}-0.1$ & $1 \times 10^{-6}$ \\
\hline wprod & Production/decay of $\mathrm{N}$ in water $\left(\mathrm{kgm}^{-3} \mathrm{~d}^{-1}\right)$ & 5 & $0.0001-0.1$ & 0.0670 \\
\hline
\end{tabular}

Rows shaded in grey correspond to parameters related to hydrological processes, while the rest are related to nitrogen processes 


\section{Nitrate-N simulations}

The HYPE model could reproduce the measured nitrate- $\mathrm{N}$ concentrations for the calibration and validation periods in a good manner (Fig. 5). The model could represent the dynamic behaviour as well as the order of magnitude of the measured nitrate- $\mathrm{N}$ concentrations. Also, the seasonal stream nitrogen concentration pattern, which was reflected by an increase in winter followed by a decrease in summer, was reproduced well by the model. The most sensitive nitrate-N-related parameters were the denitrification rate in soil (denitr) and the fraction of nutrient uptake in the uppermost soil layer (uptsoil1) of the three dominant land use classes (i.e. arable land, forest and pastures). It is known that for the biogeochemical processes, denitrification and plant uptake are low in winter and high in summer following the seasonal temperature patterns. The lower nitrate- $\mathrm{N}$ concentrations during low-flow conditions (in summer) are because of the lower nitrogen transport capacity and high retention (e.g. denitrification), and higher plant uptake because of the high temperature [31]. These findings reflect the capability of the HYPE model to represent the internal nitrogen processes and their dynamic variations controlled by the climate and flow conditions. The rest of the sensitive parameters related to nitrogen processes are listed in Table 3.

\section{Nitrogen load simulations}

As discussed above, the HYPE model showed good capability to reproduce the measured discharge and nitrate-
$\mathrm{N}$ concentrations during the calibration and validation periods (Figs. 4 and 5), resulting in good estimations of daily $\mathrm{NO}_{3}-\mathrm{N}$ loads (Fig. 6). The measured daily $\mathrm{NO}_{3}-\mathrm{N}$ loads were reproduced well by the model during both calibration and validation periods (NSE $=0.64$ and 0.67 for calibration and validations periods, respectively). The nitrate- $\mathrm{N}$ daily loads were slightly underestimated for the calibration phase (1997-2000), which was reflected by a PBIAS $=-4.67 \%$. This under-prediction mainly occurred during the winter of year 1999, where some daily nitrate- $\mathrm{N}$ load peaks were under-predicted, which was probably because of the underestimation of peak flow during the same period (Fig. 4). During the validation period, however, the daily nitrate- $\mathrm{N}$ loads were overestimated (PBIAS $=8.12 \%$ ). This was mainly because of the overestimation of the low-flow conditions (e.g. recession curves of some events during the winter of 2003). The inconsistencies between simulated daily $\mathrm{NO}_{3}-\mathrm{N}$ loads and their corresponding measured values were mainly attributed to the mismatches between the observed and predicted discharges, reflecting the importance of good hydrological simulation for representation of nitrate- $\mathrm{N}$ loads [31].

The results showed that by using a multi-objective calibration approach, $95 \%$ of the posterior uncertainty intervals of the most sensitive hydrological parameters decreased compared to stepwise calibration (results not presented here), reflecting the usefulness of multiobjective calibration to improve hydrological parameter
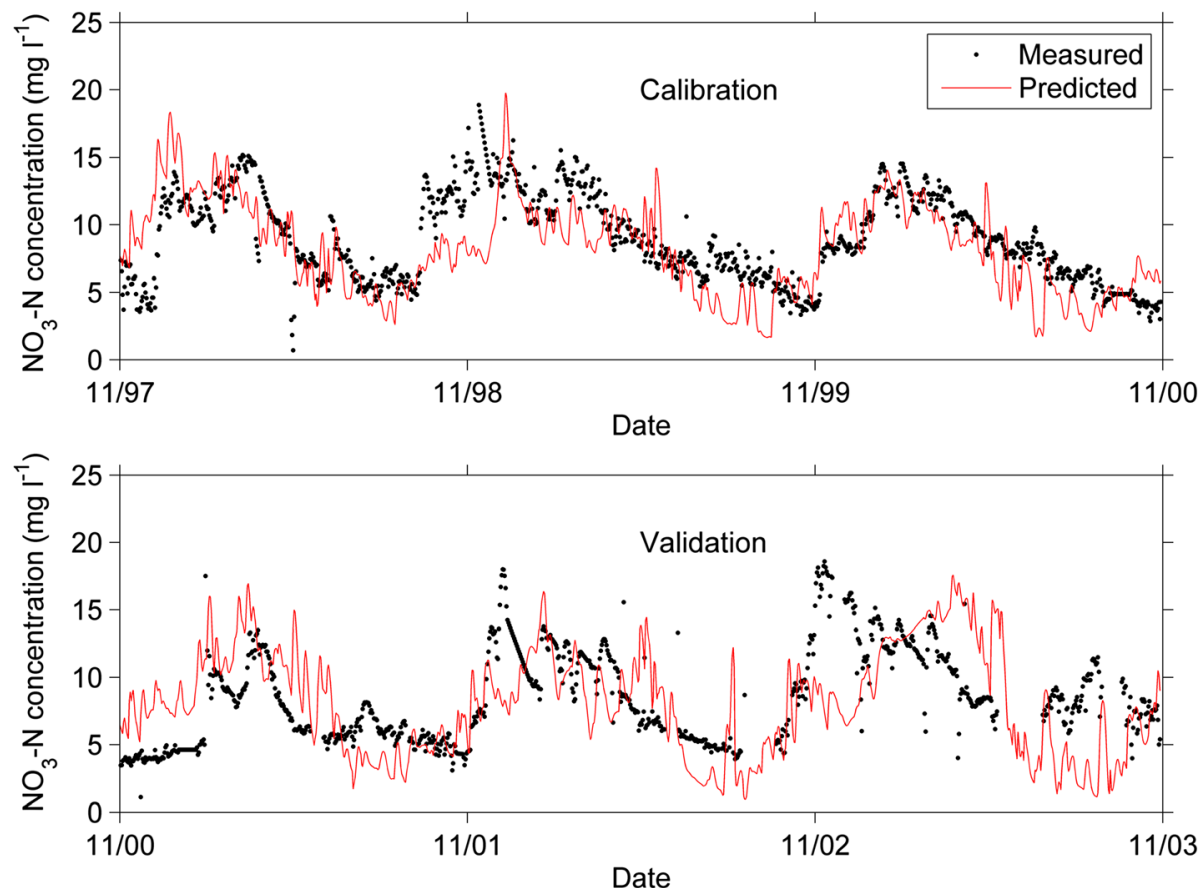

Fig. 5 Measured and predicted nitrate-N ( $\left.\mathrm{NO}_{3}-\mathrm{N}\right)$ concentrations for the Weida catchment. Two periods of three years $1997-2000$ and $2000-2003$ were used for the calibration and validation modes, respectively 

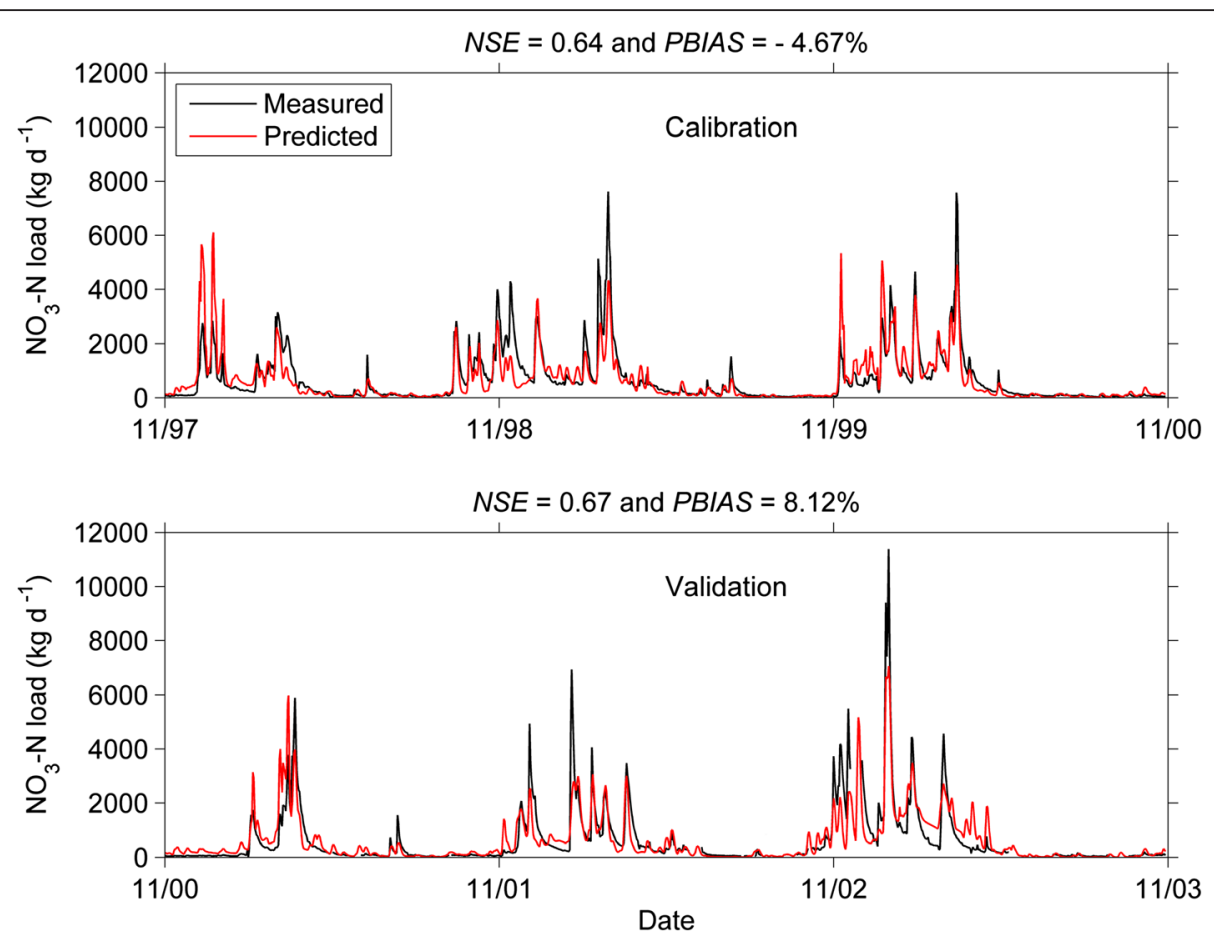

Fig. 6 Measured and predicted daily nitrate-N ( $\left.\mathrm{NO}_{3}-\mathrm{N}\right)$ load for the calibration (1997-2000) and validation (2000-2003) periods

identification. Additionally, a predictive analysis was implemented for discharge and nitrate- $\mathrm{N}$ concentration simulations using PEST [43] to investigate the effect of parameter non-uniqueness. Parameter uncertainty analysis did not result in large predictive uncertainty, especially for discharge simulation (unpublished data) compared to nitrate- $\mathrm{N}$ concentration. However, it has to be noted that PEST is a local search algorithm. Thus, the results of parameter calibration (i.e. the stability of the final optimised values) and predictive uncertainty analysis depend greatly on parameter initial values and ranges defined at the beginning of the analysis. In the ongoing work, a global approach (i.e. Monte Carlo Markov chain) will be utilised for parameter and prediction uncertainty analyses [44].

\section{Model transferability to the period 2006-2009}

The HYPE model was successfully transferred and validated temporally during the period 2006-2009 in terms of discharge and nitrate- $\mathrm{N}$ predictions using the same optimised parameters obtained for the period 19972000. The share of crops and associated fertiliser application rates were taken from the collected field survey data by the TTV authority. Monitored agriculture practice data for all fields were used as inputs to minimise the total uncertainty of the model application. Discharge simulation performance was slightly reduced in the period 2006-2009 compared to the previous period (1997-2003), where the NSE and PBIAS (for the period
2006-2009) were about 0.63 and $5.79 \%$, respectively (Fig. 7). The lower model performance could be explained by the underestimation of the three high-flow events that occurred in September 2007, April 2008 and March 2009. The model, however, reproduced the dynamical behaviour of the measured nitrate- $\mathrm{N}$ concentrations well during the period 2006-2009. The discrepancies between the measured and predicted discharges during the three extreme events resulted in the under-prediction of daily $\mathrm{NO}_{3}-\mathrm{N}$ load during these extreme events (Fig. 8a). The predicted nitrate-N load of September 29, 2007, was about $3.917 \mathrm{~kg} \mathrm{~d}^{-1}$, much lower than the measured value, which was about $14.854 \mathrm{~kg} \mathrm{~d}^{-1}$. Overall, the HYPE model could represent the measured monthly nitrate- $\mathrm{N}$ loads (Fig. 8b) reasonably well, except for the three extreme events (September 2007, April 2008 and March 2009), as explained above. This monthly simulation was taken as a baseline for the comparison of the effects of land use and agriculture practice changes on stream nitrogen loads.

\section{Effect of land use changes and agriculture management on instream water quality}

It is common in agriculture to increase fertiliser application to improve crop yield. Thus, the first designed scenario (S1) was to test the effect of increasing the fertiliser application by $20 \%$ for all crops on the stream nitrogen load. To this end, the fertiliser rates of all existing crops had increased by $20 \%$ during the simulation period. Results revealed that the $20 \%$ increase of 

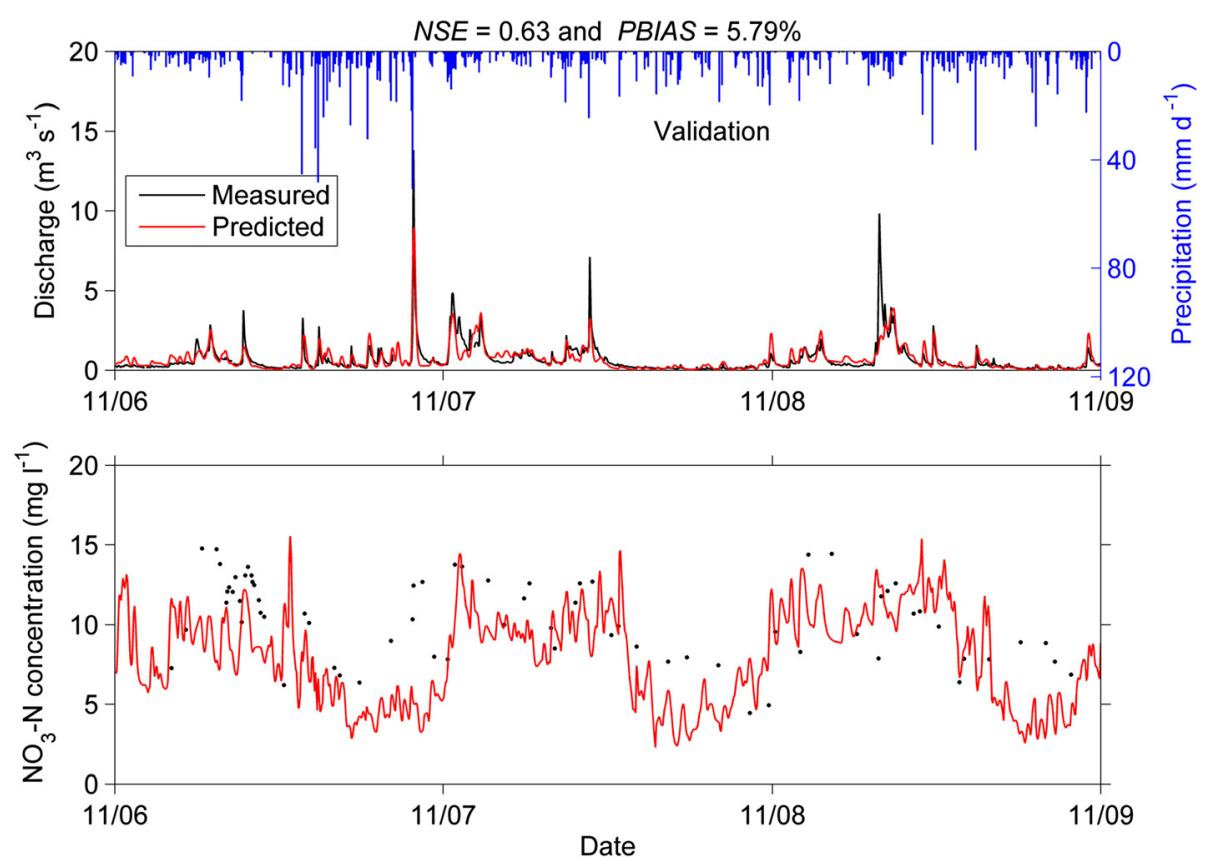

Fig. 7 Temporal validation of the HYPE model for discharge and nitrate-N concentrations in the period 2006-2009. The model could represent significantly well the hydrologic dynamical behaviour, except during some extreme events, which were underestimated resulting in reduction of NSE compared to the previous period 1997-2003. Also, the HYPE model could reproduce well the measured nitrate-N concentrations during the period 2006-2009

fertiliser amounts augmented the monthly nitrate-N loads in the range of $2-6 \%$ for the 3-year simulation period (Fig. 9a), except after the harvesting period, where the increase could achieve a range of 7-39\%. Nitrate- $\mathrm{N}$ concentrations were probably affected by the amount of mineral $\mathrm{NO}_{3}-\mathrm{N}$ left in the soil after harvesting and continuing nitrogen mineralisation in late autumn and beginning of winter [45]. The chemical fertiliser and manure were divided and added to the two topsoil layers in the proportion set by the user, allowing
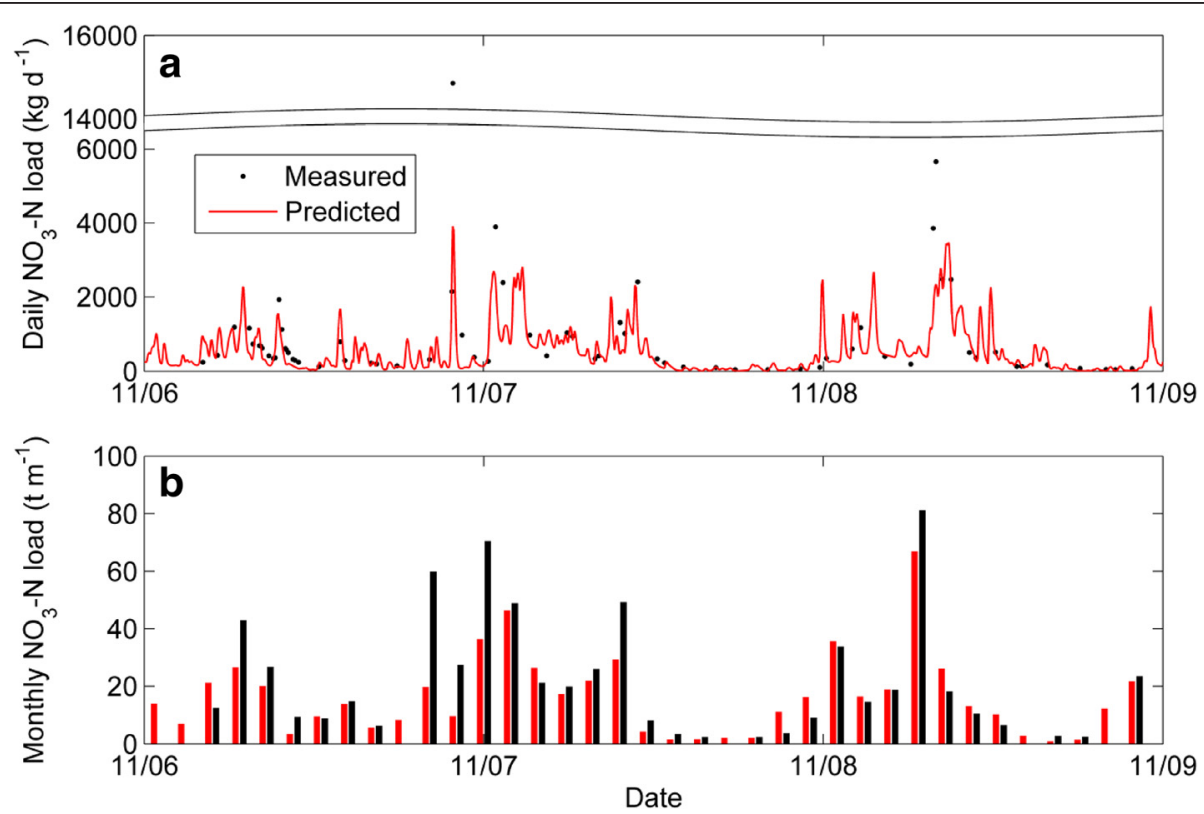

Fig. 8 Measured and predicted daily and monthly nitrate-N loads in the period 2006-2009. The HYPE model load predictions are in good agreement with the observed data at daily and monthly time steps 

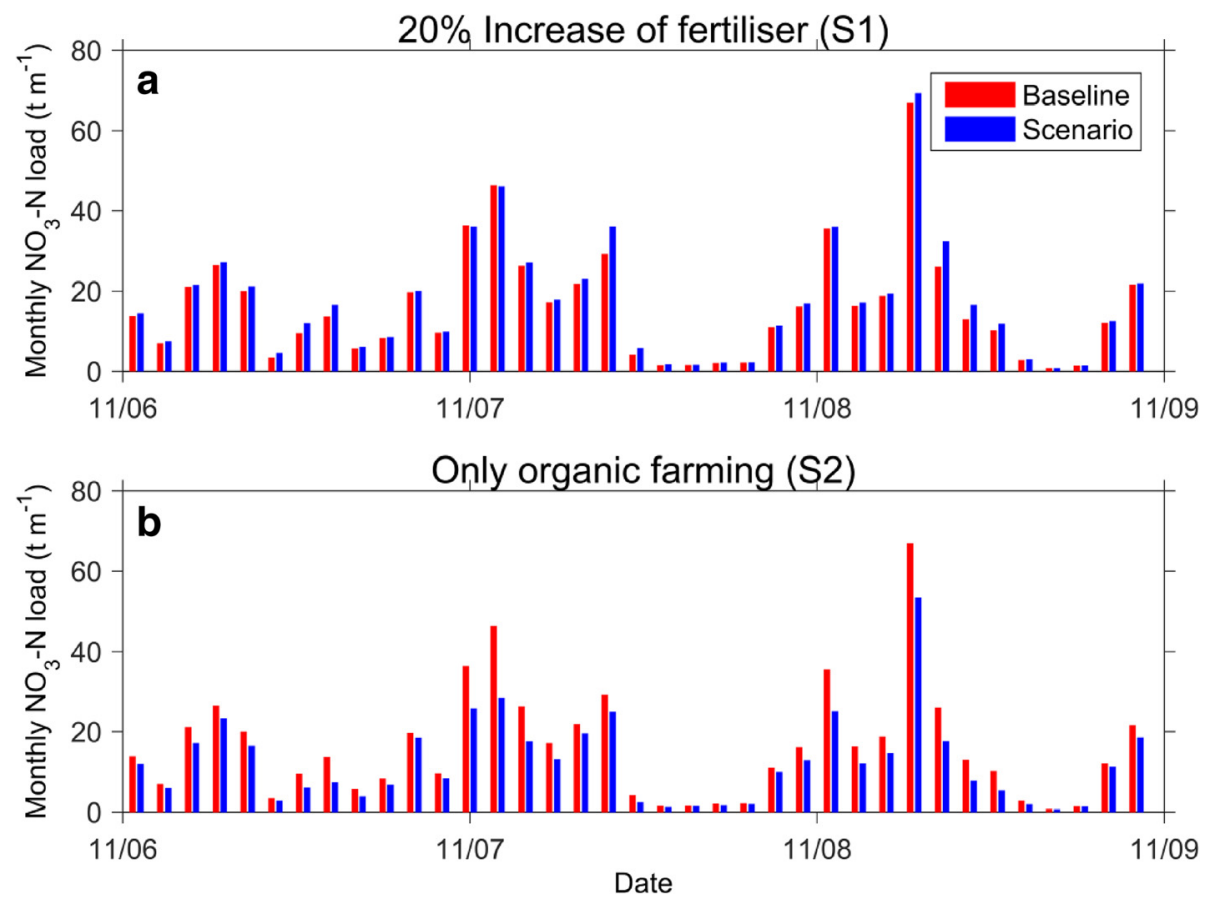

Fig. 9 Monthly nitrate-N loads for the baseline and two agriculture management scenarios for the period 2006-2009. The results showed that the nitrate-N load enriches when the fertiliser application is increased by $20 \%$ for all crops (a). While, when only organic farming is used, the $\mathrm{NO}_{3}-\mathrm{N}$ load reduces significantly compared to the baseline predictions

for simulation of different agriculture practices (such as tillage) [28].

The second scenario was designed considering only organic farming (S2). This scenario prompted the application of an average annual organic fertiliser in the range of 35.4-78.2 $\mathrm{kg} \mathrm{N}^{-1}$ year $^{-1}$ depending on the crop type (organic fertiliser rates were 69.2, 46.3, 48.6, 35.4, 78.2 and 58.4 for grassland, winter wheat, winter barley, summer barley, maize and rape, respectively). Results showed that the stream nitrate- $\mathrm{N}$ load reduced significantly during the entire simulation period, when only organic farming (no chemical fertiliser) was applied (Fig. 9b). This reduction varied from 3 to $41 \%$, and the maximum decrease was observed during winter and spring compared to the baseline predictions (where mineral and organic fertilisers were considered). It has to be noted that the efficiency of organic fertiliser is likely to be reduced by denitrification and volatile losses after its application. This process is highly influenced by plant uptake and weather conditions (temperature and rainfall patterns) and by the nitrogen turnover in the soil [45]. Thus, comparison between organic and mineral fertilisers should consider these gaseous losses.

The scenario S3 assumes that all crops are converted to maize (Fig. 10a). This induced a constant annual fertiliser application of $190.8 \mathrm{~kg} \mathrm{~N} \mathrm{ha}^{-1}$ year $^{-1}$ (divided into 112.6 and $78.2 \mathrm{~kg} \mathrm{~N}^{-1}$ for mineral and organic fertilisers, respectively) for all crops. The results showed that the nitrate- $\mathrm{N}$ load increased when all agricultural land (that were originally used by different crops) were converted to maize (Fig. 10a). The increase ranged between 1 and $5 \%$, except immediately after the application period (the first application was after ploughing and the second was 3 months after the sowing). After these two applications, the nitrogen load increased rapidly and achieved a range of 6-28 \% compared to the baseline simulations. It was seen, experimentally, that the time of harvest affected the decomposition of maize residues [10]. Soil mineralisation can additionally be affected by soil moisture content, temperature and soil aeration. This may have a strong effect on nitrogen release after the harvest, when growing maize [10]. It was experimentally shown that nitrate- $\mathrm{N}$ leaching from grassland was five times less than from silage maize [45]. This suggests that further conversion of grassland, with high soil organic matter content, to maize could increase nitrogen losses from land to water even on a regional scale [45].

When all crops were converted to summer barley (S4) and annual fertiliser application of $97.5 \mathrm{~kg} \mathrm{~N} \mathrm{ha}^{-1}$ year $^{-1}$ (62.1 and $35.4 \mathrm{~kg} \mathrm{~N} \mathrm{ha}^{-1}$ year $^{-1}$, for mineral and organic fertilisers, respectively) was considered, the monthly nitrate- $\mathrm{N}$ loads were reduced significantly compared to the baseline simulations (Fig. 10b). The nitrate-N loads were reduced in the range of 22-64\% compared to the baseline simulations for the whole period. This high nitrogen load reduction could be explained by the high 

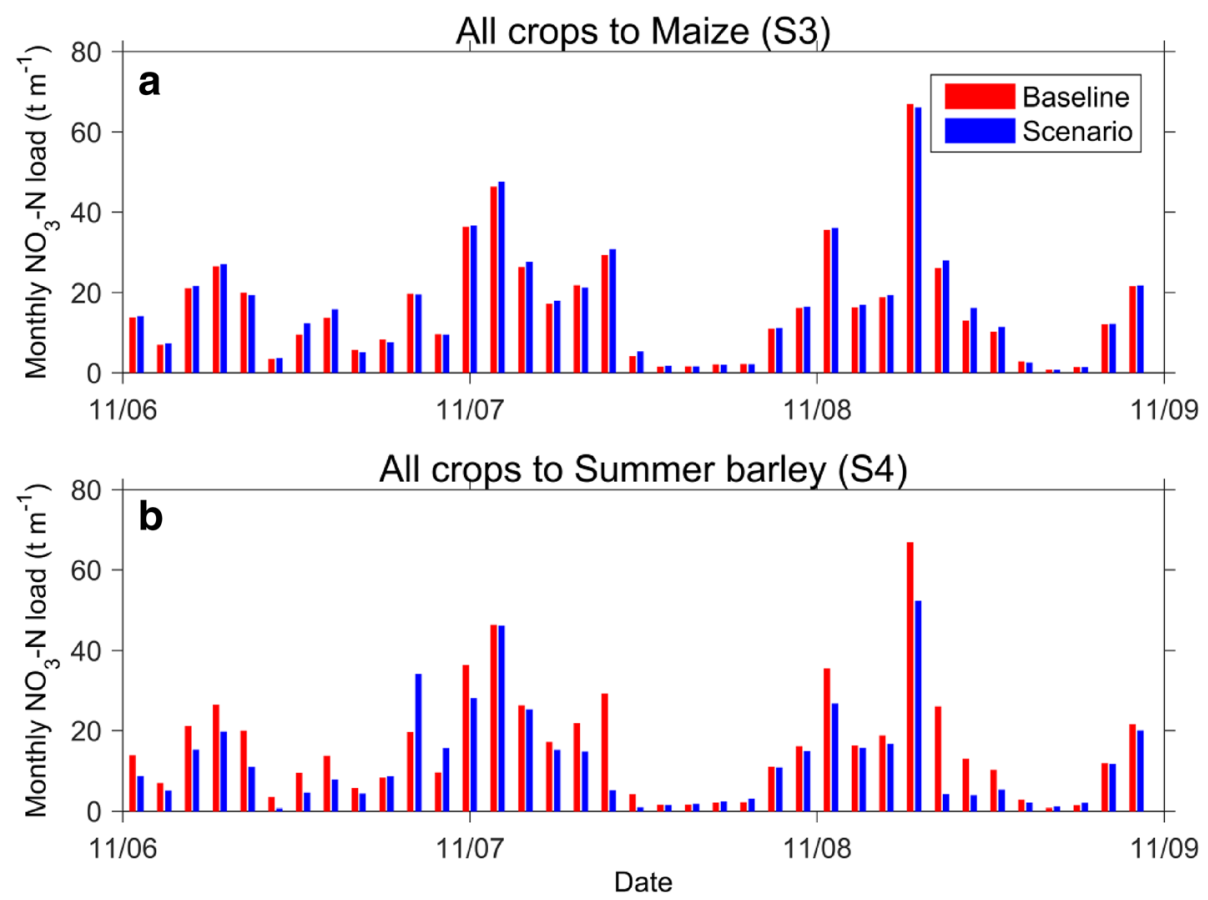

Fig. 10 Comparison between baseline monthly nitrate-N load and two agriculture scenarios. The results showed that the nitrate- $\mathrm{N}$ load was increased when all crops are converted to maize (a), while the nitrate-N load was reduced when all crops are converted to summer barley (b)

nitrogen retention (e.g. denitrification processes) during the summer because of the high temperature. It has also been noted that the decrease of nitrogen load on the account of scenario S4 (where all crops were converted to summer barley) was slightly reduced during the period August-October. This period corresponded to the afterharvesting phase of the summer barley and the early rainy autumn season, explaining an additional increase of leached nitrogen.

The results showed that converting bioenergy crops (i.e. rape and maize) to winter wheat (S5) reduced the average monthly nitrate- $\mathrm{N}$ loads of between 27 and $53 \%$ compared to baseline predictions (Fig. 11a). The nitrogen load, however, was increased only during the harvest period (June-August) within the range of 39-56\%. It is worth mentioning here that in Germany, the production of bioethanol is mostly carried out based on cereals (i.e. wheat, rye, barley and triticale). For instance, in 2011, about $80 \%$ of the bioethanol production in Germany had been produced from grains and about $20 \%$ from sugar beet [46].

When only the cropping areas of winter wheat and maize were converted to rape (S6), nitrate- $\mathrm{N}$ load was reduced (in the range of 6-19\%) during winter (November-March) and increased during spring and summer (17-60\%). The latter period corresponded to the second application of mineral fertilisers, which occurred 115 days after the sowing of rape. It is known that rape requires a high rate of fertilisers (around $200 \mathrm{~kg} \mathrm{~N} \mathrm{ha}^{-1}$ year $^{-1}$ ).

It has been reported in the literature that agricultural practices following field harvesting, such as ploughing time and ploughing type (i.e. how deep), may affect nitrogen losses from soil. The type and timing of the organic fertilisers can further affect nitrogen leaching considerably. For instance, it has been reported that deep ploughing of organic soils can lead to higher nitrogen leaching than deep ploughing of sandy soils and soils poor in organic matter [47]. Based on a previous study [31], the Weida catchment is characterised by a high denitrification coefficient $(0.0727>0.0228)$ compared to the Selke catchment located in Sachsen-Anhalt. This suggests that probably denitrification has prevented most of the nitrate- $\mathrm{N}$ from reaching the deeper groundwater. Also, the geology of the Weida catchment is characterised by clay schist and eruptive rocks, which leads to low groundwater flows.

\section{Conclusions}

A hydrological water quality (HYPE) model was setup to predict discharge and nitrate- $\mathrm{N}$ concentrations using an intensive agricultural catchment in central Germany on a daily time step. The model could reproduce the observed discharge and nitrate- $\mathrm{N}$ concentrations reasonably well, resulting in good simulations of the stream 

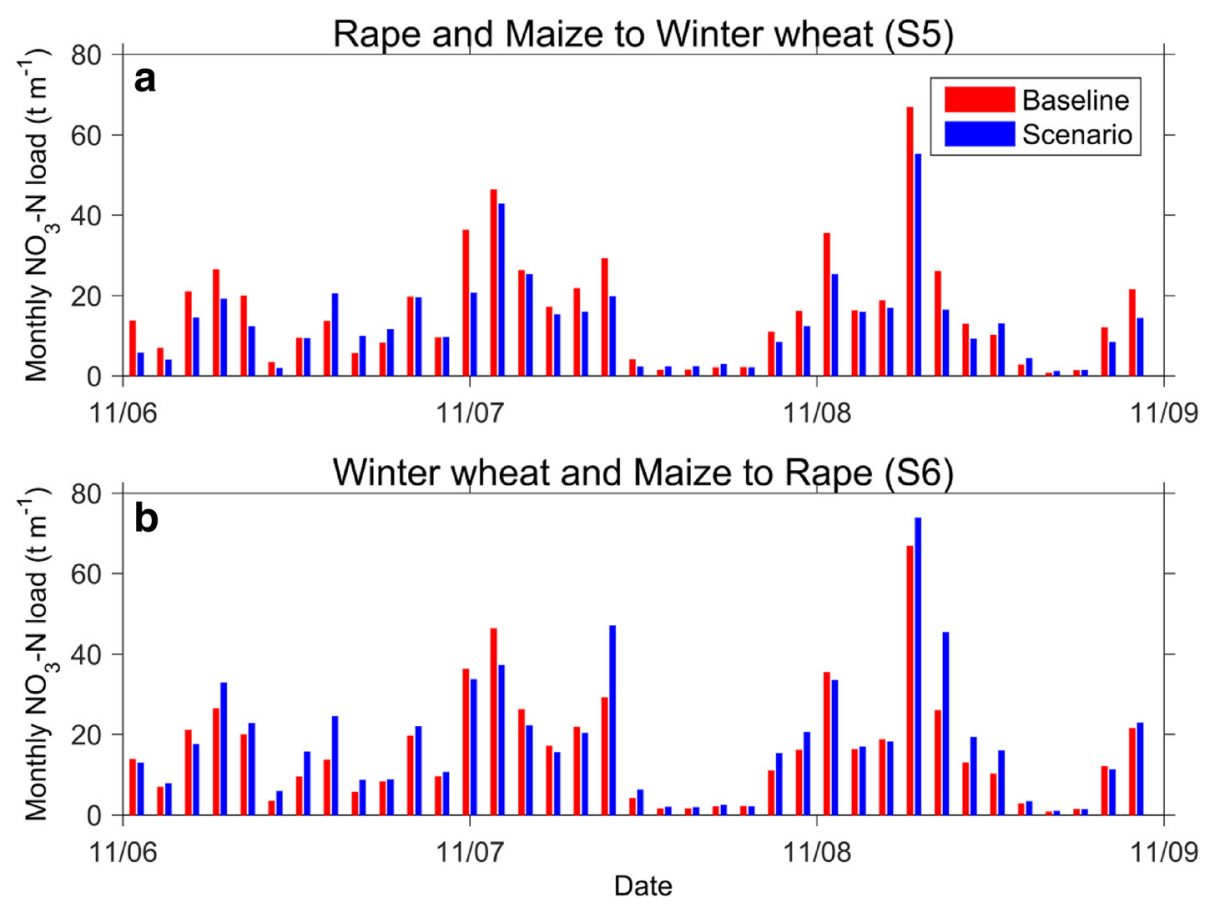

Fig. 11 Comparison between baseline and two agricultural scenarios. The nitrate-N load was decreased when all areas of rape and maize are converted to winter wheat (a). The monthly nitrate-N load, however, was increased when winter wheat and maize areas are converted to rape. This increase mainly occurred during the summer season after the crop harvesting

nitrogen load. The effect of different land use and agricultural practice changes on the stream nitrogen load was investigated using a modelling scenario approach. The results revealed that the nitrogen loads could increase or reduce rapidly depending on the designed scenario. This rapid response could be explained by the short residence times of interflow and baseflow runoff components because of the hardrock geological properties of the catchment. The nitrogen loads increased in the three scenarios where (i) mineral fertiliser was augmented by $20 \%$, (ii) all crops were converted to maize and (iii) winter wheat and maize were converted to rape. This induced either an increase of fertiliser application or increased cultivation of bioenergy crops, such as maize and rape, which were likely to increase stream nitrogen loads. On the other hand, the nitrogen load was reduced in scenarios where (i) only organic farming was practiced, (ii) only summer barley and rape were cropped and (iii) maize cropping areas were converted to winter wheat.

Also, these numerical investigations confirmed previous experimental findings reported in the literature that management options such as fertiliser amounts and its time of application could increase or reduce nitrogen load very rapidly on soils with a high mineralisation potential (e.g. coarse-textured soils). Additional management options such as the choice of dominant crops and its harvesting times could modify nitrogen load considerably.

There is a need for further detailed investigations of additional influencing factors (such as different crop rotation and different soil properties) on nitrogen leaching. Also, model uncertainties have to be considered for evaluating scenario effects. This is of significant importance of ongoing work.

\section{Competing interests}

The authors declare that they have no competing interests.

\section{Authors' contributions}

All authors designed the objectives and methods of the study. S. Jomaa, S. Jiang and MR collected the climatological, hydrological and agriculture practice datasets required for the model. DT helped to design the land use and agriculture changes. S. Jomaa and S. Jiang conducted the model setup and performed the simulations. S. Jomaa prepared the manuscript with contributions from all the co-authors. All authors read and approved the final manuscript.

\section{Acknowledgements}

The authors would like to thank Dagmar Fiedler and the guest editor Katja Bunzel for inviting us, writing an article based on our contribution to the "Biomass for energy: Lessons from bioenergy booms" in 2014 (http://www.ufz.de/biomass-lessons2014/index.php?de=33074, last accessed 11.8.2015). Moreover, we would also like to thank the reviewers for their valuable feedback and for helping to improve the final version of our article.

\section{Author details}

${ }^{1}$ Department of Aquatic Ecosystem Analysis and Management, Helmholtz Centre for Environmental Research-UFZ, Brueckstrasse 3a, 39114 Magdeburg, Germany. ${ }^{2}$ Department of Bioenergy, Helmholtz Centre for Environmental Research-UFZ, Permoserstrasse 15, 04318 Leipzig, Germany. 
${ }^{3}$ Key Laboratory of Watershed Geographic Sciences, Nanjing Institute of Geography and Limnology, Chinese Academy of Sciences, 73 East Beijing Road, Nanjing 210008, China. ${ }^{4}$ Deutsches Biomasseforschugszentrum gGmbH, Torgauer Strasse 113, 04347 Leipzig, Germany.

\section{Received: 22 September 2015 Accepted: 7 April 2016 Published online: 25 April 2016}

\section{References}

1. Souza GM, Victoria RL, Joly RC, Verdade LM (2015) 72 Bioenergy \& sustainability: bridging the gaps UNESCO. Scientific Committee on Problems of the Environment (SCOPE), Paris, in December 2013. http://rsb.org/pdfs/ reports/Bioenergy\%20and\%20Sustainability\%20-

\%20Bridging\%20the\%20Gaps.pdf

2. Graham-Rowe D (2011) Agriculture: beyond food versus fuel. Nature 474:S6. doi:10.1038/474S06a

3. Robbins M (2011) Policy: fuelling politics. Nature 474:S22. doi:10.1038/474S022a

4. Fachagentur Nachwachsende Rohstoffe e.V. (FNR) (2013) Bioenergy: the multifaceted renewable energy2013. Available http://mediathek.fnr.de/ media/downloadable/files/samples/f/n/fnr_brosch_re_bioenergie_2013_ engl._web.pdf (last accessed 26 May 2015)

5. Commission European for Renewable Energy, Road map renewable energies in the $21^{\text {st }}$ century (2007), Building a more sustainable future

6. Fräss-Ehrfeld C (2009) Renewable energy sources: a chance to combat climate change, Wolters Kluwer: law and business

7. Jackson RB, Jobbágy EG, Avissar R, Roy SB, Barrett DJ, Cook CW, Farley KA, le Maitre DC, McCarl BA, Murray BC (2005) Trading water for carbon with biological carbon sequestration. Science 310:1944. doi:10.1126/science.1119282

8. Editorial N (2007) Kill king corn. Nature 449:637. doi:10.1038/449637a

9. Fachagentur Nachwachsende Rohstoffe e. V. (FNR) (2012) Anbau nachwachsender Rohstoffe 2012 auf 2,5 Millionen Hektar 2012. Available http://www.fnr.de/presse/pressemitteilungen/aktuelle-mitteilungen/aktuellenachricht/?tx_ttnews\%5Btt_news\%5D=5713\&cHash=9c910b70ba 59c6d464ae217d5ca8e0da (last accessed 27 May 2015)

10. Müller J, Kayser M, Benke M (2011) Nitrate leaching following the cultivation of silage maize. http://www.uni-goettingen.de/de/nitrate-leaching-following-thecultivation-of-silage-maize-/55661.html (last accessed 30 July 2015)

11. Offermann FHG, Kreins P, von Ledebur O, Pelikan J, Salamon P, Sanders J (2010) Baseline 2009 to 2019: agri-economic projections for Germany. Landbauforschung - vTI Agriculture and Forestry Research 3:157

12. Schreiber $H$, Behrendt $H$, Constantinescu LT, Cvitanic I, Drumea D, Jabucar D, Juran S, Pataki B, Snishko S, Zessner M (2005) Nutrient emissions from diffuse and point sources into the River Danube and its main tributaries for the period of 1998-2000-results and problems. Water Sci Technol 51:3-4

13. Hirt U, Venohr M, Kreins P, Behrendt $H$ (2008) Modelling nutrient emissions and the impact of nutrient reduction measures in the Weser river basin, Germany. Water SciTechnol 58:11. doi:10.2166/wst.2008.833

14. Love BJ, Nejadhashemi AP (2011) Water quality impact assessment of large-scale biofuel crops expansion in agricultural regions of Michigan. Biomass Bioenergy 35:2200. doi:10.1016/j.biombioe.2011.02.041

15. Wu M, Demissie Y, Yan E (2012) Simulated impact of future biofuel production on water quality and water cycle dynamics in the Upper Mississippi river basin. Biomass Bioenergy 41:44. doi:10.1016/j.biombioe.2012.01.030

16. Pimentel D, Patzek T (2005) Ethanol production using corn, switchgrass, and wood; biodiesel production using soybean and sunflower. Nat Resour Res 14:65. doi:10.1007/s11053-005-4679-8

17. Maidl F-X, Sticksel E, Valta R (1999) Investigations for improved slurry utilization in maize. 1. Report: utilization of nitrogen, available in slurry by maize (silage and grain) using different application techniques. Ger J Agronomy 3:9

18. Dominguez-Faus R, Powers SE, Burken JG, Alvarez PJ (2009) The water footprint of biofuels: a drink or drive issue? Environ Sci Technol 43:3005. doi: 10.1021/es802162x

19. Demissie Y, Yan E, Wu M (2012) Assessing regional hydrology and water quality implications of large-scale biofuel feedstock production in the upper Mississippi River Basin. Environ Sci Technol 46:9174. doi:10.1021/es300769k

20. Valipour M (2014) Land use policy and agricultural water management of the previous half of century in Africa. Appl Water Sci. doi:10.1007/ s13201-014-0199-1

21. Arnold JG, Srinivasan R, Muttiah RS, Williams JR (1998) Large area hydrologic modeling and assessment. Part I: model development. J Am Water Resour Assoc 34:73. doi:10.1111/j.1752-1688.1998.tb05961.x
22. Arnold JG, Fohrer N (2005) SWAT2000: current capabilities and research opportunities in applied watershed modelling. Hydrol Process 19:563. doi:10.1002/hyp.5611

23. Rode M, Thiel E, Franko U, Wenk G, Hesser F (2009) Impact of selected agricultural management options on the reduction of nitrogen loads in three representative meso scale catchments in central Germany. Sci Total Environ 407:3459. doi:10.1016/j.scitotenv.2009.01.053

24. Vaché KB, Eilers JM, Santelmann MV (2002) Water quality modeling of alternative agricultural scenarios in the U.S. corn belt. J Am Water Resour Assoc 38:773. doi:10.1111/j.1752-1688.2002.tb00996.x

25. Powers SE, Ascough JC II, Nelson RG, Larocque GR (2011) Modeling water and soil quality environmental impacts associated with bioenergy crop production and biomass removal in the Midwest USA. Ecol Model 222:2430. doi:10.1016/j.ecolmodel.2011.02.024

26. Lautenbach S, Volk M, Strauch M, Whittaker G, Seppelt R (2013) Optimization-based trade-off analysis of biodiesel crop production for managing an agricultural catchment. Environ Model Softw 48:98. doi:10. 1016/j.envsoft.2013.06.006

27. Sarkar S, Miller SA (2014) Water quality impacts of converting intensivelymanaged agricultural lands to switchgrass. Biomass Bioenergy 68:32. doi:10.1016/j.biombioe.2014.05.026

28. Lindström G, Pers C, Rosberg J, Strömqvist J, Arheimer B (2010) Development and testing of the HYPE (Hydrological Predictions for the Environment) water quality model for different spatial scales. Hydrol Res 41:295 doi:10.2166/nh.2010.007

29. Jiang S, Jomaa S, Büttner O, Günter M, Michael R (2015) Multi-site identification of a distributed hydrological nitrogen model using Bayesian uncertainty analysis. J Hydrol 529:3. doi:10.1016/j.jhydrol.2015.09.009

30. Strömqvist J, Arheimer B, Dahne J, Donnelly C, Lindström G (2012) Water and nutrient predictions in ungauged basins: set-up and evaluation of a model at the national scale. Hydrol Sci J 57:229. doi:10.1080/02626667.2011.637497

31. Jiang S, Jomaa S, Rode M (2014) Modelling inorganic nitrogen leaching in nested mesoscale catchments in central Germany. Ecohydrology 7:1345. doi:10.1002/eco.1462

32. van Griensven A, Bauwens W (2003) Multiobjective autocalibration for semidistributed water quality models. Water Resour Res 39:1348. doi:10.1029/2003WR002284

33. Rode M, Suhr U, Wriedt G (2007) Multi-objective calibration of a river water quality model-Information content of calibration data. Ecol Model 204:129. doi:10.1016/j.ecolmodel.2006.12.037

34. Sivapalan M, Takeuchi K, Franks SW, Gupta VK, Karambiri H, Lakshmi V, Liang X, McDonnell JJ, Mendiondo EM, O'Connell PE, OKI T, Pomeroy JW, Schertzer D, Uhlenbrook S, Zehe E (2003) IAHS Decade on Predictions in Ungauged Basins (PUB), 2003-2012: shaping an exciting future for the hydrological sciences. Hydrol Sci J 48:857. doi:10.1623/hysj.48.6.857.51421

35. Fink M (2004) Regionale Modellierung der Wasser- und Stickstoff dynamik als Entscheidungsunterstützung für die Reduktion des N-Eintrags am Beispiel des Trinkwassertalsperrensystems Weida- Zeulenroda, Thüringen. $\mathrm{PhD}$ thesis (in German) Jena Friedrich- Schiller-Universität, ChemischGeowissenschaftliche Fakultät, Jena, p 206

36. Hesser FB, Franko U, Rode M (2010) Spatially distributed lateral nitrate transport at the catchment scale. J Environ Qual 39:193. doi:10.2134/jeq2009.0031

37. Kralisch S, Fink M, Flügel WA, Beckstein C (2003) A neural network approach for the optimisation of watershed management. Environ Model Softw 18: 815. doi:10.1016/S1364-8152(03)00081-1

38. Andersson L, Rosberg J, Pers BC, Olsson J, Arheimer B (2005) Estimating catchment nutrient flow with the HBV-NP model: sensitivity to input data. Ambio 34:521. doi:10.1579/0044-7447-34.7.521

39. Arheimer B, Löwgren M, Pers BC, Rosberg J (2005) Integrated catchment modeling for nutrient reduction: scenarios showing impacts, potential, and cost of measures. Ambio 34:513. doi:10.1579/0044-7447-34.7.513

40. Moriasi DN, Arnold JG, van Liew MW, Bingner RL, Harmel RD, Veith TL (2007) Model evaluation guidelines for systematic quantification of accuracy in watershed simulations. Transactions of the ASABE, American Society of Agricultural and Biological Engineers 50:885-900

41. Nash JE, Sutcliffe JV (1970) River flow forecasting through conceptual models part I-a discussion of principles. J Hydrol 10:282. doi:10.1016/ 0022-1694(70)90255-6

42. Littlewood IG (1995) Hydrological regimes, sampling strategies, and assessment of errors in mass load estimates for United Kingdom rivers. Environ Int 21:211. doi:10.1016/0160-4120(95)00011-9 
43. Doherty J (2005) PEST: Model independent parameter estimation, user manual, 5th edn. Watermark Numerical Computing, Brisbane

44. Laloy E, Vrugt JA (2012) High-dimensional posterior exploration of hydrologic models using multiple-try DREAM(ZS) and high-performance computing, Water Resour Res 48. doi: 10.1029/2011WR010608

45. Kayser M, Benke M, Isselstein J (2011) Little fertilizer response but high N loss risk of maize on a productive organic-sandy soil. Agron Sustain Dev 31:709. doi:10.1007/s13593-011-0046-9

46. Naumann K, Oehmichen K, Zeymer M, Meisel K (2014) DBFZ Report Nr. 11 : Monitoring Biokraftstoffsektor (2. Auflage), https://www.dbfz.de/fileadmin/ user_upload/DBFZ_Reports/DBFZ_Report11A_web.pdf. Accessed 20 Apr 2016

47. Müller U, Raissi F (2002) Arbeitshilfe für bodenkundliche Stellungnahmen und Gutachten im Rahmen der Grundwassernutzung. Niedersächsisches Landesamt für Bodenforschung, Hannover

\section{Submit your manuscript to a SpringerOpen ${ }^{\circ}$ journal and benefit from:}

- Convenient online submission

- Rigorous peer review

- Immediate publication on acceptance

- Open access: articles freely available online

- High visibility within the field

- Retaining the copyright to your article

Submit your next manuscript at $\boldsymbol{s p r i n g e r o p e n . c o m ~}$ 